\title{
Corrigendum
}

\section{Autophagy as a new therapeutic target in Duchenne muscular dystrophy}

C De Palma, F Morisi, S Cheli, S Pambianco, V Cappello, M Vezzoli, P Rovere-Querini, M Moggio, M Ripolone, M Francolini, M Sandri and $\mathrm{E}$ Clementi

Cell Death and Disease (2013) 4, e529; doi:10.1038/cddis.2013.72; published online 7 March 2013

Correction to: Cell Death and Disease (2012) 3, e418; doi:10.1038/cddis.2012.159; published online 15 November 2012

Since the publication of this article the authors have noticed the lanes displaying the actin bands in figures $1,5 \mathrm{~b}$ and supplementary figure 1 a were not the appropriate ones.
The errors have now been rectified. The article with the corrected figures appears online, together with this corrigendum.

The authors would like to apologize for any inconvenience. 